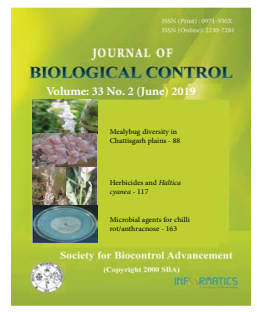

Research Article

\title{
Reproductive performance of Trichomalopsis uziae as influenced by density of its female and host (Exorista bombycis) with a note on host exposure duration for parasitism
}

\author{
J. B. NARENDRA KUMAR ${ }^{*}$, D. MANJUNATH ${ }^{2}$ and V. SIVAPRASAD ${ }^{1}$ \\ ${ }^{1}$ Central Sericultural Research and Training Institute, Central Silk Board, Govt. of India, \\ Mysuru - 570008, Karnataka, India \\ ${ }^{2}$ Department of Studies in Sericulture Science, University of Mysore, Mysuru - 570006, Karnataka, India \\ *Corresponding author E-mail: jbnarendra@gmail.com
}

\begin{abstract}
Trichomalopsis uziae Sureshan and Narendra Kumar (Hymenoptera: Pteromalidae) is a new addition to the already reported parasitoid complex of the tachinid uzi fly, Exorista bombycis (Diptera: Tachinidae), which causes 10-20\% reduction to the silkworm (Bombyx mori L.) cocoon production in the states of Karnataka, Andhra Pradesh, and Tamil Nadu. Due to the non-availability of information on its biological characteristics, an attempt has been made in the present investigation to document the parasitism impact of $T$. uziae female at various densities of its host and reproductive performance of parasitoid at ratios of 1 to 5:5 (Parasitoid: Host) and 1:1 to 50 (P: H). The reproductive performance of the parasitoid was also assessed based on the durations of host exposure for 1 to 10 days at a constant P:H ratio of 1:5. The results revealed that there was no perceptible change in the rate of parasitism at different parasitoid densities. However, the progeny production per female was significantly higher $(P<0.01)$ at a P:H ratio of 1:5 in comparison with 2:5 to 5:5. Further, at a variable host density (from 1 to 50 ), there was a linear decrease in per cent parasitism with an increase in host density and it was more drastic from a host density in exceed from 15. However, both progeny production and sex ratio increased with an increase in host density, more so from a host density upwards of 15. The host exposure duration and parasitism rate were significantly inferior at 1day exposure, while it was considerably high at other exposure periods. The progeny production was significantly higher at 2 to 5 days of exposure period without much difference in the sex-ratio.
\end{abstract}

KEY WORDS: Density, exposure duration, parasitoid, sex ratio, Trichomalopsis uziae

(Article chronicle: Received: 07-11-2018; Revised: 23-02-2019; Accepted: 20-04-2019)

\section{INTRODUCTION}

The tachinid fly, Exorista bombycis (Louis), has been a serious impediment in the production of silkworm (Bombyx mori L) cocoons in the states of Karnataka, Andhra Pradesh, and Tamil Nadu since three decades. The reduction in the production of cocoons in these states due to this tachinid fly is about $10-20 \%$ (Narayanaswamy and Devaiah, 1998). Current management strategies of uzi fly includes an IPM package comprising an exclusion, trapping, an ovicide, and an ecto-pupal parasitoid (Nesolynx thymus Girault) (Hymenoptera: Eulophidae), packing of rearing residue excluding shoot material have been advocated to combat the menace of this pest (Dandin and Giridhar, 2010; Narendra Kumar et al., 2017). Although as many as 20 parasitoids have been reported to parasitise maggot and/puparia of the uzi fly, the greater dependence has been laid presently on $N$. thymus due to its immense potential to destroy sizeable populations of E. bombycis (Narayanaswamy and Devaiah,
1998). Dependence on a single parasitoid is not a good proposition to check the menace of any pest. Recently, a new parasitoid, Trichomalopsis uziae Sureshan and Narendra Kumar (Hymenoptera: Pteromalidae) has been identified and reported to parasitize uzi pupae with a range of $44.00 \pm 4.00$ to $88.00 \pm 8.00 \%$ under laboratory conditions (Narendra Kumar et al., 2018). The exploitation of this pupal parasitoid as a biocontrol agent alongside $N$. thymus to render their combined effect would be more appreciable. Hence, the current effort focusses on the impact of the above parasitoid at various female densities and on its host as also the duration of host exposure to parasitoid on its reproductive efficiency.

It is well-known that age, size, and density of the host and parasitoid, in addition to host exposure duration to its parasitoid, play an important role in determining various biological attributes of the parasitoids such as progeny production, progeny fitness, and progeny sex ratio 
(Baitha et al., 2004; Seko and Nakasuja, 2004; Aruna, 2007; Veena, 2008, Sathe and Chougale, 2009; Venkatesan et al., 2009; Aung et al., 2011; Perveen and Sultan, 2012; Kraft and Nouhuys, 2013; Jamil et al., 2015; Kumar et al., 2016;). When host availability is surplus, it is quite expected that the parasitoid would allocate its progeny after careful estimation of host resources to maximize its progeny production, with ensuring its superior fitness and higher sex ratio. In the situations of host scarcity, the parasitoid would be compelled to allocate more progeny to host than that can ensure the occurrence of superior biological attributes of the parasitoid progeny remain to be inferior (Aruna, 2007; Gonzalez et al., 2007; Veena, 2008; Sathe and Chougale, 2009; Pomari et al., 2013; Queiroz et al., 2017). A comparable performance of the parasitoid can be expected in parasitoid female density related situations too when the host would be subjected to increased level of parasitism (Aruna, 2007; Veena, 2008; Sathe and Chougale, 2009; Pomari et al., 2013; Queiroz et al., 2017).

In the current investigation, an attempt has been made to document the impact of densities of T. uziae female and its host as also host exposure duration to parasitoid on its reproductive performance as no information is available on these aspects. Results of the investigation are expected to help planning the large-scale production of the parasitoid that would ensure fulfillment of its requirement for inundative release of $T$. uziae for the biological suppression of $E$. bombycis.

\section{MATERIALS AND METHODS}

\section{Culture of the host}

The host (uzi) pupae were obtained after allowing the post-parasitic maggots of the host collected from nearby silkworm cocoon markets to pupate at $23-28^{\circ} \mathrm{C}$ and $60-80 \%$ RH in the Pest Management Laboratory (PML) of the Central Sericultural Research and Training Institute (CSR \& TI), Mysuru.

\section{Culture of the parasitoid}

The stock cultures of $T$. uziae were maintained on the pupae of uzi fly by allowing them to parasitize the pupae at $23-28^{\circ} \mathrm{C}$ and $60-80 \% \mathrm{RH}$ in the PML. The adults of the parasitoid were fed with honey $30 \%$ as diet.

\section{Influence of Trichomalopsis uziae female density on its reproductive efficiency}

The reproductive performance of the parasitoid as influenced by its female density was scored by subjecting 3-day-old uzi pupae to parasitism by the gravid parasitoid females at host-parasitoid ratios of $5: 1$ to $5: 5$ for 5 days with ten replications. Observations were made on per cent parasitism, developmental duration, progeny production, and sex ratio.

\section{Influence of host density on the reproductive performance of Trichomalopsis uziae}

For experimentation on the impact of host density on the reproductive efficiency of $T$. uziae, a 3-day-old uzi pupae were exposed to gravid females of the parasitoid by maintaining host-parasitoid ratios of $1: 1$ to $10: 1,15: 1,20: 1,25: 1$ and 50:1 for 5 days with ten replications. Data on per cent parasitism, developmental duration, progeny production, and sex ratio were recorded.

\section{Impact of host exposure duration on parasitism by Trichomalopsis uziae}

In this experiment, mated females of the parasitoid were allowed to parasitize constant number of 3-day-old uzi fly pupae (@1P: 5H) for 1 to 10 days by maintaining 10 replications in each. After exposure of the host pupae for a specific duration (days), the parasitoid females were removed from the exposure container. Data on the developmental duration, progeny production, and sex ratio were recorded.

The data obtained on per cent parasitism, developmental duration and progeny production were analyzed using oneway ANOVA. All the statistical analysis was performed by using SPSS package (Version 21). When ANOVA was significant, the comparison of means was made by using DMRT post hoc significance test.

\section{RESULTS AND DISCUSSION}

\section{Influence of Trichomalopsis uziae female density on its re- productive performance}

The influence of $T$. uziae at various densities on its host showed a significant difference $(P<0.05)$ in the per cent parasitism among the treatments, which ranged from $82.00 \pm 3.59(5 \mathrm{P}: 5 \mathrm{H})$ and $82.00 \pm 4.67(4 \mathrm{P}: 5 \mathrm{H})$ to $54.00 \pm 9.91$ (3P: $5 \mathrm{H})$ (Table 1). The rate of parasitism was almost similar at treatments $2 \mathrm{P}: 5 \mathrm{H}(74.00 \pm 6.70)$ and $1 \mathrm{P}: 5 \mathrm{H}(70.00 \pm 8.03)$. Comparison of mean values for the parameter revealed that rate of parasitism was significantly inferior $(P<0.05)$ at $3 \mathrm{P}: 5 \mathrm{H}$ when compared with rest of the treatments where the mean results were comparable. Developmental duration of the parasitoid remained almost similar at different densities of parasitoid and host with the mean results fluctuating between $12.50 \pm 0.17$ (1P:5H) and $12.10 \pm 0.28$ (2P:5H) days. The progeny production per female was female-biased in all the treatments and the highest progeny production was noticed with $1 \mathrm{P}: 5 \mathrm{H}(30.18 \pm 2.28)$ and least with the 5P: $5 \mathrm{H}(8.09 \pm 0.55)$. There was a drastic decline in the progeny production with $2 \mathrm{P}: 5 \mathrm{H}(15.14 \pm 1.83)$ which further reduced considerably with $3 \mathrm{P}$ : $5 \mathrm{H}(9.52 \pm 1.09)$ and remaining almost 
identical with the treatments thereafter. In case of brood allocation per host, the higher brood allocation was noticed in the treatment 4P: $5 \mathrm{H}(39.90 \pm 2.37)$ and 5P: $5 \mathrm{H}(40.43 \pm 2.74)$ and was significantly $(P<0.01)$ greater than rest of the treatments. With regard to the parasitoid progeny sex ratio, the treatment with 1P: $5 \mathrm{H}(5.50 \pm 0.56)$ and $2 \mathrm{P}: 5 \mathrm{H}(4.91 \pm 0.37)$ showed significantly $(P<0.05)$ higher progeny sex ratio in comparison to rest of the treatments.

The impact of T. uziae density indicated that the female parasitoid exploited significantly more number of host pupae, indicating greater degree of parasitism, when the parasitoid-host ratios were narrower, which was quite evident in treatments with $4 \mathrm{P}: 5 \mathrm{H}$ and $5 \mathrm{P}: 5 \mathrm{H}$. This observation showed that narrowing the parasitoid-host ratio has enhanced the level of competition among the female parasitoids to exploit the fixed number of host pupae as against relatively wider parasitoid-host ratios in the remaining treatments with considerably reduced levels of per cent parasitism of host. Irrespective of per cent parasitism, the parasitoid developmental duration remained almost unchanged among the treatments. Moreover, the density of developing parasitoid progeny had no impact on the developmental duration as evidenced by the data on progeny allocation per host pupa which varied between $40.43 \pm 2.74$ (5P:5H) and $28.57 \pm 3.26(3 \mathrm{P}: 5 \mathrm{H})$ among the treatments. It is quite unlikely that the developmental duration would alter considerably up to an optimum level of progeny allocation per host that has resource level to fulfill the foraging needs of parasitoid progenies. Nonetheless, it is a well-established fact that the female parasitoid would allocate the progeny per host based on prior careful estimation of host resources (Liu et al., 2011). Further, the female parasitoid would also be careful enough to the extent that whether it should allocate femalebiased progeny or male-biased one to the host depending on the availability of resources (Werren, 1984). To be precise, the parent female would allocate relatively more of female progeny under resource-rich situation, while the opposite of it happens under resource-deficient situation (Kant et al., 2012). This could be seen in the current investigation with $T$. uziae where the parent female parasitoids allocated more of female progenies relative to male progenies when the parasitoid-host ratios were wider. Obviously, this impacted the sex ratio of the parasitoid progenies, being significantly higher when host density was more relative to parasitoid density. Even production of progenies by each of the female parasitoids vis$\grave{a}$-vis the host density supported the view that significantly more progenies would be produced under the situation with wider parasitoid-host ratio (more resource-rich) when compared to the condition with narrower parasitoid-host ratio (less resource-rich).
Sathe $(1985,1986)$ reported a decrease in parasitism with an increase in the density of parasitoids, Cotesia durani and Diadegma trichoptilus, when Exorista atomosa was parasitized. On the contrary, Perveen and Sultan (2012) working with Trichogramma chilonis Ishii observed that increase in parasitoid density resulted in significant increase in rate of parasitism with concomitant significant rise in the adult emergence without much variation among the treatments. Further, there was no significant change in the parasitoid developmental duration at various densities of the parasitoid. Mann et al. (1990) observed a low percentage of pupal mortality and parasitoid progeny emergence with low parasitoid densities than with high densities in four species of the pteromalids Muscidifurax raptor Girault and Sanders, M. zaraptor Kogan and Legner, Spalangia cameroni Perkins and S. endius Walker. Aruna (2007) observed with the eulophid parasitoid, Nesolynx thymus that the density of female parasitoid had no significant impact on the parasitoid developmental duration but had a significant positive correlation with progeny allocation per host pupa and significant negative correlation with progeny production per female and progeny sex ratio. Similar observations too were evident with the diapriid parasitoid, Trichopria sp., parasitizing the pupae of E. bombycis (Veena, 2008) and with the eulophid pupal parasitoid, Tetrastichus howardi, attacking E. bombycis (Gangadhar, 2009).

\section{Effect of host density on the reproductive efficiency of Trichomalopsis uziae}

The results on the effect of host (E. bombycis) density on the reproductive efficiency of $T$. uziae $(1 \mathrm{P}: 1 \mathrm{H}$ to $1 \mathrm{P}: 50 \mathrm{H})$ are given in Table 2 .

The per cent parasitism of the host pupae by the parasitoid, T. uziae varied between $100.00 \pm 0.00(1 \mathrm{P}: 1 \mathrm{H})$ and $24.60 \pm 1.58(1 \mathrm{P}: 50 \mathrm{H})$ among the treatments. It declined with increase in the host density from 1 to 50 . The per cent parasitism decreased drastically from a host density of 3 $(60.00 \pm 2.59)$ onwards and remained more or less constant to a host density of $5(68 \pm 2.17)$.

There was a further slump in the per cent parasitism from a host density of $6(41.66 \pm 3.46)$ and again increased to a host density of $10(53.00 \pm 3.73)$ but without any significant difference. A further decrease in per cent parasitism was noticed as host density increase from 15 (30.66 \pm 2.55$)$ and to $50(24.60 \pm 1.58)$. Comparison of mean results was significant $(P<0.01)$ statistically among the treatments. There was significant difference in the developmental duration of parasitoid among the treatments which ranged from $13.60 \pm 0.22$ (host density of 20 ) to $12.50 \pm 0.17$ days 
Table 1. Impact of density of parasitoid on the reproductive performance of Trichomalopsis uziae when host density is constant

\begin{tabular}{|c|c|c|c|c|c|c|c|c|c|}
\hline \multirow{2}{*}{$\begin{array}{c}\text { Para- } \\
\text { sitoid: } \\
\text { host } \\
\text { density }\end{array}$} & \multirow[b]{2}{*}{$\begin{array}{l}\text { Per cent } \\
\text { parasitism }\end{array}$} & \multirow[b]{2}{*}{$\begin{array}{l}\text { Develop. } \\
\text { Duration }\end{array}$} & \multicolumn{3}{|c|}{ Brood allocation per pupa } & \multicolumn{3}{|c|}{ Progeny production per female } & \multirow[b]{2}{*}{$\begin{array}{c}\text { Sex ratio } \\
\text { (females pe } \\
\text { male) }\end{array}$} \\
\hline & & & Male & Female & Total & Male & Female & Total & \\
\hline $1: 5$ & $70.00 \pm 8.03^{\mathrm{ab}}$ & $12.50 \pm 0.17$ & $4.64 \pm 0.62^{b}$ & $25.54 \pm 1.79^{\mathrm{ab}}$ & $30.18 \pm 2.28^{\mathrm{b}}$ & $4.64 \pm 0.62^{\mathrm{a}}$ & $25.54 \pm 1.79^{\mathrm{a}}$ & $30.18 \pm 2.28^{\mathrm{a}}$ & $5.50 \pm 0.56^{\mathrm{a}}$ \\
\hline $2: 5$ & $74.00 \pm 6.70^{\mathrm{ab}}$ & $12.10 \pm 0.28$ & $5.12 \pm 0.66^{\mathrm{ab}}$ & $25.16 \pm 3.14^{\mathrm{ab}}$ & $30.28 \pm 3.65^{b}$ & $2.56 \pm 0.33^{\mathrm{ab}}$ & $12.58 \pm 1.57^{\text {ab }}$ & $15.14 \pm 1.83^{\mathrm{ab}}$ & $4.91 \pm 0.37 \mathrm{ab}$ \\
\hline $3: 5$ & $54.00 \pm 9.91^{\mathrm{b}}$ & $12.30 \pm 0.15$ & $5.59 \pm 0.71^{\mathrm{ab}}$ & $22.65 \pm 2.78^{b}$ & $28.57 \pm 3.26^{\mathrm{b}}$ & $1.87 \pm 0.24^{\mathrm{b}}$ & $7.55 \pm 0.93^{b}$ & $9.52 \pm 1.09^{\mathrm{b}}$ & $4.04 \pm 0.56^{\mathrm{b}}$ \\
\hline $4: 5$ & $82.00 \pm 4.67^{\text {a }}$ & $12.30 \pm 0.15$ & $8.27 \pm 0.79^{\mathrm{a}}$ & $31.63 \pm 1.90^{\mathrm{a}}$ & $39.90 \pm 2.37^{\mathrm{a}}$ & $2.07 \pm 0.19^{\mathrm{b}}$ & $7.91 \pm 0.48^{\mathrm{b}}$ & $9.98 \pm 0.59^{\mathrm{b}}$ & $3.82 \pm 0.31^{\mathrm{b}}$ \\
\hline $5: 5$ & $82.00 \pm 3.59^{\mathrm{a}}$ & $12.40 \pm 0.16$ & $7.84 \pm 0.65^{\mathrm{a}}$ & $32.59 \pm 2.35^{\mathrm{a}}$ & $40.43 \pm 2.74^{\mathrm{a}}$ & $1.57 \pm 0.13^{b}$ & $6.17 \pm 0.48^{\mathrm{b}}$ & $8.09 \pm 0.55^{b}$ & $3.93 \pm 0.35^{\mathrm{b}}$ \\
\hline F-value & $2.741 *$ & $0.619 \mathrm{NS}$ & $5.774 * *$ & $3.172 *$ & $3.960 * *$ & $4.364 * *$ & $3.257^{* *}$ & $4.224 * *$ & $3.559^{* *}$ \\
\hline
\end{tabular}

Values given in the Table are the mean of 10 replications (Mean $\pm \mathrm{SE}$ ); Mean values followed by the same superscript in columns are statistically not significant; ** - Significant at $1 \%$; * Significant at $5 \%$; NS - Non-significant

Table 2. Influence of host density on the reproductive performance of Trichomalopsis uziae

\begin{tabular}{|c|c|c|c|c|c|c|c|c|c|}
\hline \multirow{2}{*}{$\begin{array}{l}\text { Host } \\
\text { density }\end{array}$} & \multirow{2}{*}{$\begin{array}{c}\text { Per cent } \\
\text { parasitism }\end{array}$} & \multirow{2}{*}{$\begin{array}{l}\text { Develop- } \\
\text { mental } \\
\text { Duration }\end{array}$} & \multicolumn{3}{|c|}{ Progeny production } & \multicolumn{3}{|c|}{ Brood allocation per pupa } & \multirow{2}{*}{$\begin{array}{c}\text { Sex Ratio } \\
\text { (females per male) }\end{array}$} \\
\hline & & & Male & Female & Total & Male & Female & Total & \\
\hline 1 & $100 \pm 0.00^{\mathrm{a}}$ & $12.6 \pm 0.163^{\mathrm{cd}}$ & $13.2 \pm 0.061^{\mathrm{bcd}}$ & $33.3 \pm 0.024^{\mathrm{d}}$ & $46.5 \pm 0.030^{\mathrm{cd}}$ & $13.2 \pm 0.061^{\mathrm{a}}$ & $33.3 \pm 0.024^{\mathrm{a}}$ & $46.5 \pm 0.030^{\mathrm{a}}$ & $2.52 \pm 0.044^{\mathrm{de}}$ \\
\hline 2 & $90.00 \pm 5.99^{\mathrm{a}}$ & $12.7 \pm 0.213^{\mathrm{cd}}$ & $20.6 \pm 0.078^{\mathrm{ab}}$ & $49.8 \pm 0.070^{\text {cd }}$ & $70.4 \pm 0.073^{\text {bcd }}$ & $12.5 \pm 0.070^{\mathrm{a}}$ & $29.0 \pm 0.077^{\mathrm{ab}}$ & $42.5 \pm 0.064^{\mathrm{a}}$ & $2.32 \pm 0.025^{\mathrm{e}}$ \\
\hline 3 & $60.00 \pm 2.59^{\mathrm{b}}$ & $12.5 \pm 0.167^{\mathrm{d}}$ & $9.7 \pm 0.1010^{\mathrm{d}}$ & $33.8 \pm 0.071^{\mathrm{d}}$ & $43.5 \pm 0.079^{\mathrm{d}}$ & $5.2 \pm 0.079^{\mathrm{bc}}$ & $18.65 \pm 0.053^{\mathrm{cd}}$ & $23.85 \pm 0.060^{\mathrm{bc}}$ & $3.59 \pm 0.054^{\mathrm{bc}}$ \\
\hline 4 & $57.50 \pm 5.56^{\mathrm{b}}$ & $12.7 \pm 0.153^{\mathrm{cd}}$ & $15.1 \pm 0.097^{\text {abcd }}$ & $44.4 \pm 0.098^{\mathrm{d}}$ & $59.5 \pm 0.095^{\text {cd }}$ & $7.42 \pm 0.088^{b}$ & $19.05 \pm 0.059^{\text {cd }}$ & $26.47 \pm 0.065^{\mathrm{bc}}$ & $2.57 \pm 0.070^{\text {cde }}$ \\
\hline 5 & $68.00 \pm 2.17^{\mathrm{b}}$ & $12.8 \pm 0.249^{\mathrm{cd}}$ & $9.9 \pm 0.073^{\text {cd }}$ & $42.7 \pm 0.084^{\mathrm{d}}$ & $52.6 \pm 0.084^{\mathrm{cd}}$ & $5.23 \pm 0.054^{\mathrm{bc}}$ & $22.45 \pm 0.060^{\mathrm{b}}$ & $27.68 \pm 0.061^{\mathrm{b}}$ & $4.29 \pm 0.020^{\mathrm{bc}}$ \\
\hline 6 & $41.66 \pm 3.46^{\mathrm{cd}}$ & $12.8 \pm 0.249^{\mathrm{cd}}$ & $10.4 \pm 0.080^{\mathrm{cd}}$ & $40.5 \pm 0.072^{\mathrm{d}}$ & $50.9 \pm 0.072^{\mathrm{cd}}$ & $4.14 \pm 0.042^{\mathrm{bc}}$ & $16.59 \pm 0.047^{\mathrm{cd}}$ & $20.74 \pm 0.043^{\mathrm{bc}}$ & $4.01 \pm 0.043^{\mathrm{bcd}}$ \\
\hline 7 & $51.42 \pm 1.84^{\text {bc }}$ & $13.3 \pm 0.396^{\mathrm{abc}}$ & $14.3 \pm 0.032^{\text {abcd }}$ & $50.4 \pm 0.049^{\mathrm{cd}}$ & $64.7 \pm 0.044^{\mathrm{bcd}}$ & $4.02 \pm 0.025^{\mathrm{bc}}$ & $14.19 \pm 0.045^{\mathrm{de}}$ & $18.21 \pm 0.040^{\mathrm{cd}}$ & $3.52 \pm 0.026^{\text {cde }}$ \\
\hline 8 & $51.25 \pm 4.29^{\mathrm{bc}}$ & $13.1 \pm 0.314^{\text {abcd }}$ & $13.7 \pm 0.085^{\mathrm{bcd}}$ & $39.3 \pm 0.096^{\mathrm{d}}$ & $53.0 \pm 0.092^{\mathrm{cd}}$ & $3.53 \pm 0.045^{\mathrm{cd}}$ & $9.31 \pm 0.030^{\mathrm{f}}$ & $12.84 \pm 0.030^{\text {de }}$ & $2.64 \pm 0.042^{\mathrm{de}}$ \\
\hline 9 & $41.11 \pm 4.55^{\mathrm{cd}}$ & $13.8 \pm 0.389^{\mathrm{a}}$ & $11.8 \pm 0.092^{\mathrm{cd}}$ & $40.3 \pm 0.109^{\mathrm{d}}$ & $52.1 \pm 0.10^{\mathrm{d}}$ & $3.22 \pm 0.039^{\text {cde }}$ & $10.99 \pm 0.015^{\mathrm{ef}}$ & $13.70 \pm 0.047^{\mathrm{de}}$ & $3.41 \pm 0.034^{\mathrm{cde}}$ \\
\hline 10 & $53.00 \pm 3.73^{\mathrm{bc}}$ & $12.9 \pm 0.233^{\mathrm{bcd}}$ & $17.0 \pm 0.080^{\mathrm{abc}}$ & $56.0 \pm 0.101^{\text {cd }}$ & $73.0 \pm 0.09^{\mathrm{bcd}}$ & $3.23 \pm 0.043^{\text {cde }}$ & $9.99 \pm 0.048^{\text {ef }}$ & $13.22 \pm 0.047^{\mathrm{de}}$ & $3.09 \pm 0.034^{\mathrm{cde}}$ \\
\hline 15 & $30.66 \pm 2.55^{\mathrm{d}}$ & $13.0 \pm 0.000^{\mathrm{bcd}}$ & $10.7 \pm 0.084^{\mathrm{cd}}$ & $44.3 \pm 0.064^{\mathrm{cd}}$ & $55.0 \pm 0.06^{\mathrm{cd}}$ & $2.29 \pm 0.032^{\text {def }}$ & $9.97 \pm 0.026^{\text {ef }}$ & $12.26 \pm 0.024^{\mathrm{e}}$ & $4.35 \pm 0.046^{\mathrm{bc}}$ \\
\hline 20 & $32.50 \pm 2.18^{\mathrm{d}}$ & $13.6 \pm 0.221^{\mathrm{ab}}$ & $12.9 \pm 0.060^{\mathrm{bcd}}$ & $72.6 \pm 0.058^{\mathrm{bc}}$ & $85.5 \pm 0.057^{\mathrm{bc}}$ & $2.05 \pm 0.035^{\mathrm{ef}}$ & $11.26 \pm 0.032^{\mathrm{ef}}$ & $13.31 \pm 0.032^{\mathrm{de}}$ & $5.49 \pm 0.038^{\mathrm{b}}$ \\
\hline 25 & $26.80 \pm 1.39^{\mathrm{d}}$ & $13.4 \pm 0.163^{\mathrm{abc}}$ & $9.8 \pm 0.066^{\mathrm{cd}}$ & $90.8 \pm 0.059^{\mathrm{b}}$ & $99.8 .6 \pm 0.060^{\mathrm{b}}$ & $1.38 \pm 0.026^{\mathrm{f}}$ & $13.08 \pm 0.026^{\text {def }}$ & $14.46 \pm 0.026^{\text {de }}$ & $9.49 \pm 0.028^{\mathrm{a}}$ \\
\hline 50 & $24.60 \pm 1.58^{\mathrm{d}}$ & $13.4 \pm 0.163^{\mathrm{abc}}$ & $22.7 \pm 0.028^{\mathrm{a}}$ & $253.4 \pm 0.018^{\mathrm{a}}$ & $276.1 \pm 0.015^{\mathrm{a}}$ & $1.92 \pm 0.0154^{\mathrm{ef}}$ & $21.01 \pm 0.045^{\mathrm{bc}}$ & $23.38 \pm 0.037^{\mathrm{bc}}$ & $10.94 \pm 0.033^{\mathrm{a}}$ \\
\hline $\mathrm{f}$-value & $27.37 * *$ & $2.76^{* *}$ & $3.58 * *$ & $10.18^{* *}$ & $8.60 * *$ & $18.15^{* *}$ & $11.69^{* *}$ & $15.01^{* *}$ & $15.84 * *$ \\
\hline
\end{tabular}

Values given in the Table are the mean of 10 replications (Mean \pm SE); Mean values followed by the same superscript in columns are statistically not significant; ** - Significant at $1 \%$; - Significant at $5 \%$; NS - Non-significant

(host density of 3). The brood allocation per host varied between $46.50 \pm 0.03$ to $12.26 \pm 0.02$ at a host density of 1 to 15 , While there was no difference in the brood allocation at the host density of $3(23.85 \pm 0.06)$ up to $7(18.21 \pm 0.04)$. At a host density of 8 , the brood allocation stood at $12.84 \pm 0.03$ and these remained almost similar up to a host density of 25 (14.46 \pm 0.03$)$. At a host density of 50, the brood allocation was $23.38 \pm 0.04$. In all the treatments, the allocation of progenies by the female parasitoid was highly female biased. The maximum progeny production was noticed at a host 
density of $50(276.10 \pm 0.02)$ and minimum at $3(43.5 \pm 0.08)$. There was no consistency in the production of progenies vis-à-vis host density, which varied considerably among the treatments. However, it showed a spurt in the progeny production at host densities from 20 onwards. The production of male and female progenies exhibited the trend observed for total progenies which was greatly in favor of females. The parasitoid progeny sex ratio was distinctly superior $(P<0.01)$ at host densities of $25(1: 9.49 \pm 0.03)$ and $50(10.94 \pm 0.03)$. At other treatments, it varied from $5.49 \pm 0.04$ (host density of 20) to $2.32 \pm 0.03$ (host density of 2). In the present study the per cent parasitism of T. uziae decreased with increase in density of host. The parasitoid developmental duration significantly increased with increase in host density, possibly due to reduced allocation of brood to each of the hosts so as to facilitate the effective development of the parasitoid under resource-rich situation. With regard to progeny production and progeny sex ratio, the results were comparable for the respective parameters up to a host density of 15 pupae; thereafter, the progeny production greatly increased with sex ratio being female-biased.

On the influence of host density vis-à-vis the reproductive performance, a host of studies have been conducted in many parasitoids. They adjust their clutch size/brood allocation depending on the host density. In many cases, it was found that they lay more eggs on a host that was scarcely available and allocation of eggs or clutch size decreases as the host density increases (Aruna, 2007; Veena, 2008). By contrast, Gangadhar (2009) noticed that there was no influence of host density on the brood allocation in T. howardi while Veena (2008) and Gangadhar (2009), in their studies with Trichopria sp. and T. howardi, respectively, found a significant positive correlation between host density and parasitoid developmental duration, Jamil et al. (2015) recorded maximum number of egg laying in Bracon hebetor (Say.) at high host density compared to a single host. Also, egg deposition increased with increase in density of host. However, the parasitoid optimized its clutch size to avoid overcrowding of eggs on host's body. They also observed maximum egg hatching at highest host density as compared to a single host which may be due to less crowding of eggs on host larvae. Consequently, percentage adult emergence was also greater at highest host density, due to less larval competition for foraging during the course of development. With regard to sex ratio, they recorded that it increased as the host density increased.

Perveen and sultan (2012) reported that developmental duration and adult longevity were not significantly different at all host egg densities tested in T. chilonis. In addition, adult emergence was highest at minimum and lowest at maximum host egg densities. Kraft and Nouhuys (2013) studied the gregarious parasitoid, Pteromalus apum Retzius preying on two co-occurring butterfly species, Melitaea cinxia and $M$. athalia. It was found that host density affected life-history and population traits of the parasitoid. Low host density resulted in high superparasitism and with larger brood size. Also, a positive correlation was observed between brood size and sex ratio among broods at low host density because of superparasitism, while negligible correlation was found among broods at high host density. In the present investigation, high host density resulted in the production of more progenies as well as female biased sex ratio. Similarly, Perveen and Sultan (2012) studied the impact of host density on the biological parameters of T. chilonis and observed that at different densities of host eggs, the rate of parasitism was significantly different depending on the host species tested. With the host, Sitotroga cerealella, the rate of parasitism increased significantly with an increase in host egg number up to certain extent and then started declining. However, adult emergence gradually decreased with increase in host density. With the host species of Corcyra cephalonica, there was not much relationship between host density and parasitism, though adult emergence significantly reduced with increase in host density. Mann et al. (1990) found that when the varying number of hosts was exposed to a constant number of parasitoids, it resulted in gradual increase in the average parasitism as well as average progeny production, while increasing the number of host pupae killed per parasitoid as well as progeny production per parasitoid.

\section{Impact of host exposure duration on the reproductive effectiveness of Trichomalopsis uziae}

The data on the influence of host exposure duration on the reproductive effectiveness of T. uziae, are furnished in Table 3.

The results of per cent parasitism by $T$. uziae ranged from $96.00 \pm 2.67$ (3-days exposure) to $56.00 \pm 5.81$ (1-day exposure) among the treatments. The rate of parasitism was significantly inferior $(P<0.01)$ in treatment with 1 -day exposure in comparison to the most treatments, while it was somewhat comparable with a few other treatments $(7,9$, and 10-day exposure). The minimum parasitoid developmental duration was noticed at 1-day $(11.70 \pm 0.15$ days $)$ and maximum at 8 -day ( $13.60 \pm 0.16$ days) of exposure period. The results of exposure duration from 1 to 5-days were similar, while significant difference $(P<0.01)$ was observed once the exposure period was increased from 6 to 10-days. The brood allocation by $T$. uziae female fluctuated between $39.42 \pm 3.27$ (4-day) and $20.57 \pm 1.40$ (1-day). Barring the allocation at 1-day, the allocation up to 5-days was significantly higher $(P<0.01)$ in comparison to rest of the treatments without any significant difference. The similar trend was observed 
Table 3. Duration of exposure of host pupa (Exorista bombycis) and its impact on the reproductive performance of Trichomalopsis uziae

\begin{tabular}{|c|c|c|c|c|c|c|c|c|c|c|}
\hline \multirow{2}{*}{$\begin{array}{l}\text { Days } \\
\text { of } \\
\text { exp }\end{array}$} & \multirow{2}{*}{$\begin{array}{c}\text { Per cent } \\
\text { parasitism }\end{array}$} & \multirow{2}{*}{$\begin{array}{l}\text { No. of pupa } \\
\text { parasitised }^{(}\end{array}$} & \multirow{2}{*}{$\begin{array}{l}\text { Develop. } \\
\text { Duration }\end{array}$} & \multicolumn{3}{|c|}{ Total Progeny production } & \multicolumn{3}{|c|}{ Progeny production per pupa } & \multirow{2}{*}{$\begin{array}{c}\text { Sex Ratio } \\
\text { (females } \\
\text { per male) }\end{array}$} \\
\hline & & & & Male & Female & Total & Male & Female & Total & \\
\hline 1 & $56.00 \pm 5.81^{\mathrm{c}}$ & $2.80 \pm 0.29^{\mathrm{c}}$ & $11.70 \pm 0.15^{\mathrm{c}}$ & $14.25 \pm 1.91^{\mathrm{cd}}$ & $43.34 \pm 2.76^{d}$ & $57.59 \pm 3.78^{c}$ & $5.09 \pm 0.63^{\mathrm{c}}$ & $15.48 \pm 1.30^{\mathrm{d}}$ & $20.57 \pm 1.40^{\mathrm{d}}$ & $3.04 \pm 0.52$ \\
\hline 2 & $88.00 \pm 3.27^{\mathrm{ab}}$ & $4.40 \pm 0.16^{\mathrm{ab}}$ & $12.00 \pm 0.00^{\mathrm{c}}$ & $27.00 \pm 2.67^{\mathrm{bc}}$ & $132.90 \pm 8.30^{\mathrm{ab}}$ & $159.90 \pm 10.38^{\mathrm{a}}$ & $6.10 \pm 0.51^{\mathrm{c}}$ & $30.19 \pm 1.63^{\mathrm{a}}$ & $\underset{\mathrm{ab}}{36.29 \pm 1.98}$ & $4.95 \pm 0.32$ \\
\hline 3 & $96.00 \pm 2.67^{\text {a }}$ & $4.80 \pm 0.13^{\mathrm{a}}$ & $12.10 \pm 0.23^{\mathrm{c}}$ & $33.00 \pm 3.09^{\mathrm{ab}}$ & $144.80 \pm 5.20^{\mathrm{a}}$ & $178.80 \pm 7.75^{a}$ & $6.90 \pm 0.67$ ab & $30.34 \pm 1.36^{\mathrm{a}}$ & $37.24 \pm 1.92^{\mathrm{a}}$ & $4.39 \pm 0.35$ \\
\hline 4 & $84.00 \pm 5.81^{\mathrm{ab}}$ & $4.20 \pm 0.29^{\mathrm{ab}}$ & $12.00 \pm 0.00^{\mathrm{c}}$ & $38.80 \pm 4.91^{\mathrm{a}}$ & $124.40 \pm 10.60^{\mathrm{ab}}$ & $163.20 \pm 14.56^{\mathrm{a}}$ & $9.39 \pm 1.10^{\mathrm{a}}$ & $30.03 \pm 2.37^{\mathrm{a}}$ & $39.42 \pm 3.27^{\mathrm{a}}$ & $3.19 \pm 2.72$ \\
\hline 5 & $88.00 \pm 3.27$ ab & $4.40 \pm 0.16^{\mathrm{ab}}$ & $12.10 \pm 0.23^{\mathrm{c}}$ & $37.20 \pm 3.13^{\mathrm{a}}$ & $118.20 \pm 6.78^{b}$ & $155.40 \pm 8.16^{\mathrm{a}}$ & $8.62 \pm 0.81$ ab & $26.81 \pm 1.11^{\mathrm{ab}}$ & $\underset{\mathrm{ab}}{35.43 \pm 1.54}$ & $3.25 \pm 0.27$ \\
\hline 6 & $78.00 \pm 6.29^{a b}$ & $3.90 \pm 0.31$ ab & $13.30 \pm 0.21^{\mathrm{ab}}$ & $18.50 \pm 1.14^{\mathrm{cd}}$ & $75.20 \pm 4.53^{\mathrm{c}}$ & $93.70 \pm 5.36^{\mathrm{b}}$ & $4.98 \pm 0.42^{\mathrm{c}}$ & $19.89 \pm 1.15^{\mathrm{cd}}$ & $\underset{\text { cd }}{24.87 \pm 1.51}$ & $3.99 \pm 0.23$ \\
\hline 7 & $68.00 \pm 8.00^{\mathrm{bc}}$ & $3.40 \pm 0.40^{\mathrm{bc}}$ & $13.10 \pm 0.18^{\mathrm{ab}}$ & $21.90 \pm 3.38^{\mathrm{cd}}$ & $67.70 \pm 7.66^{c}$ & $90.60 \pm 10.16^{b}$ & $6.70 \pm 0.97$ ab & $22.10 \pm 3.19^{a b}$ & $\underset{\text { bc }}{28.80 \pm 4.03}$ & $3.29 \pm 0.95$ \\
\hline 8 & $76.00 \pm 7.18^{a b}$ & $3.80 \pm 0.36^{\mathrm{ab}}$ & $13.60 \pm 0.16^{\mathrm{a}}$ & $17.40 \pm 1.72^{\mathrm{cd}}$ & $66.50 \pm 6.15^{\mathrm{c}}$ & $83.90 \pm 7.76^{b}$ & $4.77 \pm 0.42^{\mathrm{bc}}$ & $17.94 \pm 1.19^{\mathrm{cd}}$ & $\underset{\text { cd }}{22.70 \pm 1.59}$ & $3.80 \pm 0.19$ \\
\hline 9 & $72.00 \pm 9.04^{\mathrm{bc}}$ & $3.60 \pm 0.45^{\mathrm{bc}}$ & $12.90 \pm 0.18^{\mathrm{b}}$ & $19.50 \pm 3.03^{\mathrm{cd}}$ & $66.90 \pm 8.05^{\mathrm{c}}$ & $86.70 \pm 10.64^{b}$ & $5.51 \pm 0.87^{\mathrm{c}}$ & $21.48 \pm 3.51 \mathrm{ab}$ & $\underset{\mathrm{cd}}{26.99 \pm 4.12}$ & $3.90 \pm 0.93$ \\
\hline 10 & $70.00 \pm 8.03^{\mathrm{bc}}$ & $3.50 \pm 0.40^{\mathrm{bc}}$ & $13.00 \pm 0.21^{\mathrm{b}}$ & $18.40 \pm 2.71^{\mathrm{cd}}$ & $69.20 \pm 7.49^{\circ}$ & $87.60 \pm 9.87^{b}$ & $5.45 \pm 0.68^{\mathrm{c}}$ & $21.63 \pm 3.05^{\mathrm{ab}}$ & $\underset{\text { cd }}{27.08 \pm 3.63}$ & $3.97 \pm 0.30$ \\
\hline $\begin{array}{c}\mathrm{f}- \\
\text { value }\end{array}$ & $3.485^{* *}$ & $3.485^{* *}$ & $14.241^{* *}$ & $8.995^{* *}$ & $26.192 * *$ & $22.565^{* *}$ & $4.417^{* *}$ & $6.633^{* *}$ & $6.286^{* *}$ & $0.843 \mathrm{NS}$ \\
\hline
\end{tabular}

Values given in the Table are the mean of 10 replications (Mean $\pm \mathrm{SE}$ ); Mean values followed by the same superscript in columns are statistically not significant; @ - Out of 5 pupae provided for parasitization; ** - Significant at 1\%; NS - Non-significant

in the progeny production per female, as observed for brood allocation. With reference to progeny sex ratio, the results were not differing significantly among the treatments.

The reproductive potential of parasitic hymenoptera is reported to be affected by many factors, including optimum exposure period of the host to the parasitoid. Kumar et al. (2016) studied the impact of exposure of T. howardii female to the host pupa of sugarcane stalk borer, Chilo auricilius (Dudgeon), and observed significantly more number of adults emerging from the host which was exposed for $24 \mathrm{~h}$ compared to $48,72,96$, and $120 \mathrm{~h}$. The percentage female production was maximum at $24 \mathrm{~h}$ exposure duration followed by 48,72 , and $4 \mathrm{~h}$. There was no significant difference in the developmental period in the treatments. Further, when the parasitoid was exposed to $C$. partellus for varying durations, Baitha et al. (2004) recorded no parasitism at $1 \mathrm{~h}$ exposure and maximum and minimum of progenies at 12 and $2 \mathrm{~h}$ exposure, respectively. As the exposure duration prolonged $(>12 \mathrm{~h})$, the number of adults emerging per pupa did not increase significantly. However, upon dissection, such pupae were observed to contain a number of partially developed parasitoids. The female progeny production was greatest in $12 \mathrm{~h}$ exposure and it declined significantly with increase in exposure period.
From the foregoing account, it can be concluded that density of T. uziae female and its host, E. bombycis, as also the duration of the host exposure to the parasitoid have significant influence on the parasitoid reproductive parameters such as per cent parasitism, brood allocation per host, progeny production per female, and progeny sex ratio. The information thus generated would throw light on mass production of the parasitoid in question when such an attempt is contemplated in future for its field release either singly or in association with other parasitoids, especially $N$. thymus which is currently exploited under biological control program of $E$. bombycis.

\section{ACKNOWLEDGEMENTS}

Authors are grateful to Dr. K. V. Ashalatha, Professor and Head, Department of Agricultural Statistics, University of Agricultural Sciences, Dharwad, Karnataka, and Dr. S. H. Divya, Faculty, Yuvaraja's College, Mysuru, Karnataka, for help in statistical analysis of experimental data.

\section{REFERENCES}

Aruna AS. 2007. Developmental dynamics of an Eulophid ecto-pupal parasitoid (Nesolynx thymus) on some Dipteran hosts. Ph.D. Thesis submitted to the University 
of Mysore, Manasagangothri, Mysuru, Karnataka, India. $291 \mathrm{pp}$.

Aung KSD, Takagi M, Myint YY, Tun KM, Ueno T. 2011. Effect of host density on the progeny production of the egg parasitoids Ooencyrtus nezarae (Ishii) (Hymenoptera: Encyrtidae). J Fac Agri Kyushu Univ. 56: $71-74$.

Baitha A, Jalali SK, Rabindra RJ, Venkatesan T, Rao NS. 2004. Parasitising efficiency of the pupal parasitoid, Tetrastichus howardi (Olliff) (Hymenoptera: Eulophidae) on Chilo partellus (Swinhoe) at different exposure periods. J Biol Control 18: 65-68.

Dandin SB, Giridhar K. 2010. Hand Book of Sericulture Technologies, pp. 452-456. Central Silk Board.

Gonzalez PI, Montoya P, Lachoud GP, Cancino J, Liedo P. 2007. Superparasitism in mass reared Diachasmimorpha longicaudata (Hymenoptera: Braconidae), a parasitoid of fruit flies (Diptera: Tephritidae). Biol Control 40: 320326. https://doi.org/10.1016/j.biocontrol.2006.11.009

Gangadhar B. 2009. Biology and evaluation of Tetrastichus howardi (Olliff) (Hymenoptera: Eulophidae) with reference to some hosts. Ph.D. Thesis submitted to University of Mysore, Manasagangothri, Mysuru, Karnataka, India, $251 \mathrm{pp}$.

Jamil A, Abdin ZU, Arshad M, Falabella P, Abbas S.K, Tahir M, Jamil A, Manzoor A, Shaina H. 2015. Multiple effects of host density on egg density and sex ratio of progeny of Bracon hebetor (Say.) (Hymenoptera: Braconidae). Pakistan J Zool. 47(2): 455-460.

Kant R, Minor MA, Trewick SA, Sandanayaka WRM. 2012. Body size and fitness relation in male and female Diaeretiella rapae. BioControl 57: 759-766. https://doi.org/10.1007/s10526-012-9452-4

Kraft T, Nouhuys SV. 2013. The effect of multi-species host density on superparasitism and sex ratio in a gregarious parasitoid. Ecol Entomol. 38: 138-146. https://doi.org/10.1111/een.12004

Kumar A, Baitha A, Bareliya PK. 2016. Some biological aspects of pupal parasitoid, Tetrastichus howardi (Olliff) (Hymenoptera: Eulophidae) on Chilo auricilius (Dudgeon) pupae. Current Biotica 10: 170-174.

Liu Z, Xu B, Li L, Sun J. 2011. Host-size mediated trade-off in a parasitoid sclerodermus harmandi (Hym: Bethylidae). PLoS ONE. 6: e23260. https://doi.org/10.1371/journal. pone.0023260 PMid:21853096 PMCid:PMC3154928
Mann JA, Stinner RE, Axtell RC. 1990. Parasitism of house fly (Musca domestica) pupae by four species of Pteromalidae (Hymenoptera): effects of host-parasitoid densities and host distribution. Med Vet Entomol. 4: 235-243. https://doi.org/10.1111/j.1365-2915.1990. tb00433.x PMid:2132987

Narayanaswamy KC, Devaiah MC. 1998. Silkworm uzi fly. Zen Publishers, Bangalore. pp. 232.

Narendra Kumar JB, Manjunath D. 2018. Impact of age and size of host on the reproductive performance of an ectopupal parasitoid, Trochomalopsis uziae Sureshan \& Narendra Kumar. Sericologia 58: 17-27.

Narendra Kumar JB, Vinod Kumar, Sivaprasad V. 2017. Holistic approach for effective management of silkworm uzi fly, Exorista bombycis (Louis) (Diptera: Tachinidae). Sericologia 57: 53-57.

Perveen F, Sultan R. 2012. Effects of the host and parasitoid densities on the quality production of Trichogramma chilonis on lepidopterous (Sitotroga cerealella and Corcyra cephalonica) eggs. Arthropoda 1: 63-72.

Pomari AF, Bueno ADF, Junior RCODF, Oliveiras MD, Fonseca ACPF. 2013. Releasing number of Telenomus remus (Nixon) (Hymenoptera:Platygastridae) against Spodoptera frugiperda Smith (Lepidoptera: Noctuidae) in corn, cotton and soybean. Ciência Rural 43: 377-382. https://doi.org/10.1590/S0103-84782013005000013

Queiroza AP, Buenob AF, Pomari AF, Bortolottod OC, Mikamid AY, Olivee L. 2017. Influence of host preference, mating, and release density on the parasitism of Telenomus remus (Nixon) (Hymenoptera, Platygastridae). Rev Bras Entomol. 61: 86-90. https://doi.org/10.1016/j.rbe.2016.12.004

Sathe TV. 1984. Host parasitoid density relationship between Exelastis atomosa Wals. (Lep., Pterophoridae) and Cotesia orentalis Chalikwar \& Nikam (Hymenoptera: Braconidae). Oikoassay 2: 20-21.

Sathe TV. 1985. Host parasitoid density relationship between Exelastis atomosa Wals. (Lep., Pterophoridae) and Cotesia diurnii R. \& N. (Hymenoptera: Braconidae). Comp Physio Ecol. 10: 271-272.

Sathe TV. 1986. Effect of parasitoid density on parasitism by Diadegma trichoptilus (Cameron). Geobios 13: $173-174$.

Sathe TV, Chougale TM. 2009. Effect of parasitoid density on parasitism of Mythimna separata Fab by Dolichogenidea 
Mythimna S. and B. (Braconidae: Hymenoptera). Biol Forum An Int J. 1: 75-76.

Seko T, Nakasuja F. 2004. Effects of egg size variation on survival rate, development and fecundity of offspring in a migrant skipper, Parnara guttata (Lepidoptera: Hesperiidae). App Ent Zool. 39: 171-176. https://doi.org/10.1303/aez.2004.171

Veena N. 2008, Investigations on the biology and development of an endo-pupal parasitoid, Trichopria sp. (Hymenoptera: Diapriidae), in the tachinid fly, Exorista bombycis (Louis). Ph.D. Thesis submitted to University of Mysore, Manasagangothri, Mysuru, Karnataka, India, $161 \mathrm{pp}$.

Venkatesan T, Srinivasa Murthy K, Rabindra RJ, Baskaran TV. 2009. Influence of parasitoid-host density on the behavior ecology of Goniozus nephantidis (Muesebeck) (Hymenoptera: Bethylidae), a parasitoid of Opisina arenosella Walker. J Biol Control 23: 255-264.

Werren JH. 1984. A model for sex ratio selection in parasitic wasps: Local mate competition and host quality effects. Netherlands $J$ Zool. 34: 81-96. https://doi.org/10.1163/002829684X00056 